\title{
Human Capital of Siberia in The Epoch of the Digital Economy Development
}

\author{
Anna A. Aletdinova* and Aleksey V. Koritskiy \\ Novosibirsk State Technical University \\ 20 Karl Marks Str., Novosibirsk, 630073, Russia
}

Received 02.06.2017, received in revised form 03.11.2017, accepted 14.11.2017

\begin{abstract}
The change of employees' functions and the creation of network interaction conditions have led to employment expansion, change of working time patterns, blurring of geographical boundaries, increased flexibility of work and transfer of economic and social activities to cyberspace. In the era of digital economy, human capital has become in more demand and has gained greater impact. This is confirmed by calculations and interpretation of the modified Mintzer's equation. Employees should be constantly engaged in personal development, continual education; they should be able to think critically and systematically, quickly adapt to changing environment; be fluent in foreign languages, strive to achieve goals, and be set up for success. The results of the survey show that freelancers meet these requirements better in contrast to workers with a standard form employment.
\end{abstract}

Keywords: Digital Economy, Network Interaction, Human Capital, Psychodiagnostic Methods, Modified Mincer's Equation.

DOI: 10.17516/1997-1370-0162.

Research area: economics.

As noted by V.I. Vernadsky, the noosphere is a harmonic connection of nature and society, the triumph of reason and humanity, where science, community development and public policy merge together for the benefit of man, a world without weapons, wars and environmental problems, it is a dream, a goal, facing the people of good will, a belief in the great mission of science and humanity, armed with science. This is a single organized whole all parts of which are harmoniously connected on various levels and act in concert with each other. A necessary condition for its existence is a fast, reliable, long-distance connection between these parts, a continual material exchange between them, and a comprehensive exchange of information (Vernadsky, 2004). V.I. Vernadsky singled out the basic prerequisites for the advent of the noosphere:

- man's occupation of the whole surface of the planet and their victory in competition with other biological species;

- the discovery of new sources of energy, such as nuclear energy, which enables human activity to become an important geological force;

- the victory of democracy and the increased role of the masses in matters of foreign and domestic policy;

(c) Siberian Federal University. All rights reserved

* Corresponding author E-mail address: aletdinova@corp.nstu.ru 
Table 1. Distinctive features of the digital economy

\begin{tabular}{|c|c|c|}
\hline \multirow{2}{*}{ Feature } & \multicolumn{2}{|c|}{ Type of economy } \\
\hline & Industrial & Digital \\
\hline $\begin{array}{l}\text { Formation of a network method of } \\
\text { economic relations coordination } \\
\text { (Smorodinskaya, 2015) }\end{array}$ & $\begin{array}{l}\text { The system with vertical } \\
\text { subordination and the control } \\
\text { center } \\
\text { The traditional market system with } \\
\text { price signals }\end{array}$ & $\begin{array}{l}\text { Cluster-network systems with } \\
\text { horizontal connections and } \\
\text { collaboration mechanism }\end{array}$ \\
\hline $\begin{array}{l}\text { The development of economic } \\
\text { activities }\end{array}$ & $\begin{array}{l}\text { Mining and processing } \\
\text { industry }\end{array}$ & $\begin{array}{l}\text { Services: education, entertainment, } \\
\text { health, finance, etc. } \\
\text { Transfer of Activities to } \\
\text { Cyberspace }\end{array}$ \\
\hline $\begin{array}{l}\text { The predominant form of } \\
\text { knowledge }\end{array}$ & explicit & implicit \\
\hline Type Society & Industrial & Post-industrial, information \\
\hline The prevailing types of innovation & Scientific and Technical & Open \\
\hline Main resources & Capital, entrepreneurial ability & Information, human capital \\
\hline $\begin{array}{l}\text { Approaches to research and } \\
\text { development work }\end{array}$ & $\begin{array}{l}\text { Growth of investments in industry } \\
\text { and agriculture }\end{array}$ & $\begin{array}{l}\text { Growth of investments in creative } \\
\text { and information industries }\end{array}$ \\
\hline
\end{tabular}

- the development of worldwide communication systems, the creation of a unified information system for humanity;

- a significant increase in the population's science involvement (Vernadsky, 2004).

It can be said now that we are in the process of implementation of the fourth and fifth stages. Information and knowledge have become the main source of competitiveness for an employee or an industrial enterprise.

Back in 2003, researchers began to write about the emergence of cyberspace and arising socio-economic effects (Vdovenko, Kharchenko, 2003; Kuehl, 2009).

The developing digital economy is changing the ways of economic relations coordination, the type of society and its needs, necessary basic resources and types of activity, the approach to research and development and the role of knowledge (Table 1).

With the increasing information capacity of economic systems and the transition to the postindustrial economy, there is a move away from the strict hierarchy of organization and interaction. Vertical structures are too rigid to meet the sharply increased dynamism of the external environment. A new method of coordination is required, expressed in clusternetwork systems with horizontal links and the collaboration mechanism (Smorodinskaya, 2015).

Knowledge in a broad sense is understood as all the acquirements and abilities of a person which can be used to solve problems, make decisions and understand received information. In cyberspace, it is consciously or unconsciously used by individuals (Badinger, Tondl, 2002).

As far back as 1994, R.F. Abdeev singled out the main components of the intensification of information processes which have appeared now: a constantly increasing speed of message transmission; an increase in the amount of information transmitted; a higher speed of information processing; fuller use of feedbacks; an increase in the volume of new information and the speed, at which it is implemented; a visual display of information to a person during operations; more technically equipped management work (Abdeev, 1994). 
Networking has engulfed not only social communities, but also administration at all levels of government, economics and education. There are certain advantages of network structures:

- adaptability to changing conditions, fast reaction to market changes;

- concentration of network participants on their key competencies and unique processes;

- a significant reduction in transaction costs, their rational structure;

- no risk of functions duplication by network members;

- the possibility of cooperation in projects within the network for competent partners, who have necessary resource potential;

- an effective mechanism for information exchange between network members, replicating best practices.

The following strategic guidelines for the development of the digital space by 2025 have already been determined:

- improved seamlessness of economic processes and the service environment as a result of their transformation to a digital format;

- digitization of physical objects and territories;

- system digital transformations of countries' economies in the direction of integration and business initiatives;

- creation and launch of joint digital tools for expansion into global markets;

- effective use of open data in the interests of business entities and citizens;

- the qualitative growth in the number of jobs in the digital economy;

- the reduction of complex economic risks;

- reducing costs of citizens, small and medium-sized businesses in the operation in digital environment;

- the emergence of sustainable digital ecosystems (Gimpel'son, Luk'yanova, 2006).
In our opinion, digitalization of the economy is possible under the following conditions:

- the development of digital infrastructures and communication standards;

- ensuring information security;

- the growth of online education;

- provision of free access to the network for all citizens and online communications within it;

- an improved control of data flows and knowledge in digital ecosystems;

- the formation of digital culture and accumulation of human capital.

The key factor in the success of digital transformation is the development of digital culture and providing organizations with relevant specialists. This conclusion is supported by the results of the Digital IQ study, which examines the effect of investments in digital technologies and systems (De la Fuente, Ciccone, 2002). Eventually, the success of the transformation will depend not on special sensors, algorithms or analytical tools, but on human capital. Organizations need to attract, retain and train "digital generation" specialists, employees who can safely work in dynamic digital ecosystems.

\section{Theoretical framework}

The technological revolution fundamentally changed human capital management in organizations. With the optimization of logistics tasks in cyberspace, increased speed of information transfer and reduced costs of its search new social and labor forms appeared, access to talents became wider, and the "wars" for them have increased (Fulk, DeSanctis, 1995; Privman et al., 2013, Kane et al., 2017). Digital economy development and flexible approaches to the organizational structure led to a significant growth of distributed work in cyberspace (Aubert, Kelsey, 2003). As a result, new ways of accumulating human capital appeared. 
Adam Smith, in his book "An Inquiry into the Nature and Causes of the Wealth of Nations", asserted that wages should compensate or equalize the difference in the advantages and disadvantages of different work activities (Government of the RF, 2011). It was him who developed the concept of human capital.

G.N. Tuguskina defines human capital as an aggregate of the following components: innate abilities, health, motives and interests, creative and cultural potentials, accumulated and developed as a result of knowledge investment and professional experience, which are necessary for a certain sphere of professional activity, contribute to the growth of labour productivity and bring income (Tuguskin, 2009). Consequently, the components of human capital can be represented by innate abilities, health, motives and interests, knowledge, professional experience, creative and cultural potential.

G. Becker's point of view coincides with the previous one. He notes that not only knowledge and skills acquired by an individual, but also motivation is important in human capital (Becker, 1975).

V. Radaev regards human capital as a limited resource, which can be accumulated, possesses liquidity i. e. the ability to turn into the money form, as well as the ability to convert, reproducing in the process of the continuous circuit in forms and bringing new, additional cost (Radaev, 2003). R. Nureyev points out two aspects in the interpretation of human capital:

- human capital as a reservoir, that is a specific form of capital embodied in the person himself; it's a reservoir of health, knowledge, skills, abilities, motivations that a person possesses and that contributes to the growth of his labor productivity and brings income in the form of wages or rent. Its structure comprises innate abilities, general culture, special knowledge, acquired abilities, skills and experience, as well as the ability to apply them in appropriate time and place;

- human capital as a stream of earnings due to investments in this resource (Nureyev, 2009).

Consequently, at the present time human capital is viewed as the result of targeted investments into a person. This is the part of human personality, determined by natural and social properties and abilities. We hold the view that human capital is a set of accumulated knowledge, abilities and skills, health, a system of motivation which can influence organizational and increase a person's income.

In the conditions of economy digitalization, human capital, which has the following properties, is mostly needed (Table 2).

In "The Atlas of new professions" there are ten cross-professional competencies which are in great demand in the conditions of innovative economy. They are systems thinking, crossindustry communication skills, ability to manage projects, lean manufacturing, programming, robotics, intelligence, client focus, multilingual and multicultural abilities, working with people, ability to work under

uncertainty, creative abilities (Gimpel'son, Luk'yanova, 2006). Emerging new professions require that specialists use software. The change in the functions of employees and the created conditions for network interaction led to the expansion of forms of employment, the change of working time patterns, blurring of geographical boundaries, increased flexibility of work and transfer of economic and social activities to the Internet environment.

In order to maintain competitiveness, organizations need to create innovations, therefore, employees must change their behavior. This requires an innovative culture. The key competencies of the innovation community, reflected in the draft Concept of Innovative Development until 2020, are: 
Table 2. Main features characterizing a psychological portrait of human capital which are the most significant for the digital economy

\begin{tabular}{|c|c|c|}
\hline Feature group & Feature & Literary sources \\
\hline \multirow[t]{9}{*}{ Intellectual } & $\begin{array}{l}\text { Ability and readiness for continual } \\
\text { education }\end{array}$ & $\begin{array}{l}\text { (Government of the RF, 2011; } \\
\text { Schultz, 1971; } \\
\text { Levchenko, Tsarenko, 2016) }\end{array}$ \\
\hline & Striving for improvement & (Levchenko, Tsarenko, 2016) \\
\hline & Readiness for retraining & (Schultz, 1971; Levchenko, 2016) \\
\hline & Professional mobility & \multirow[t]{2}{*}{ (Kupriyanovskiy et al., 2017) } \\
\hline & Openness to novelty & \\
\hline & $\begin{array}{l}\text { Ability to think critically and } \\
\text { systematically }\end{array}$ & $\begin{array}{l}\text { (Luksha et al., 2014; Government of the RF, } \\
\text { 2011; OECD, 2016) }\end{array}$ \\
\hline & Creativity & $\begin{array}{l}\text { (Government of the RF, 2011; Kupriyanovskiy } \\
\text { et al., 2017) }\end{array}$ \\
\hline & Self-development, self-improvement & (Government of the RF, 2011) \\
\hline & Seeking for non-standard solutions & (Kupriyanovskiy et al., 2017) \\
\hline \multirow[t]{3}{*}{ Communicative } & Fluency in foreign languages & (Luksha et al., 2014) \\
\hline & $\begin{array}{l}\text { Readiness to work independently as well } \\
\text { as in a team }\end{array}$ & $\begin{array}{l}\text { (Government of the RF, 2011; Kupriyanovskiy et } \\
\text { al., 2017; Persinger et al., 2011) }\end{array}$ \\
\hline & $\begin{array}{l}\text { Freedom, independence from people and } \\
\text { commitments }\end{array}$ & (Persinger et al., 2011) \\
\hline \multirow[t]{5}{*}{ Motivational } & Reasonable risk acceptance & (Government of the RF, 2011) \\
\hline & Entrepreneurial spirit & (Government of the RF, 2011) \\
\hline & Self-reliance, self-confidence & (Kupriyanovskiy et al., 2017) \\
\hline & The pursuit of success & (Persinger et al., 2011) \\
\hline & Flexibility, adaptability & (Kupriyanovskiy et al., 2017) \\
\hline
\end{tabular}

- ability and readiness for continuous education, continuous improvement, retraining and self-education, professional mobility, love of novelty;

- the ability to think critically;

- ability and readiness for reasonable risk, creativity and enterprise, ability to work independently and readiness to work in a team, readiness to work in a highly competitive environment;

- a broad command of foreign languages as communication tools for effective participation in the processes of globalization, including the ability to communicate freely in English on every day, business and professional topics (Government of the RF, 2016).

T. Schultz writes: "All human resources and abilities are either congenital or acquired.
Every person is born with individual set of genes, defining congenital human potential. Under human capital we mean valuable qualities acquired by a person that can be strengthened by corresponding investments" (Schultz, 1971). The ability to learn faster than competitors is perhaps the only sustainable competitive advantage (Kirnen, 2004). Continuing education is also mentioned in the works of O.M. Levchenko, I.O. Tsarenko (Levchenko, Tsarenko, 2016).

\section{Scientists E.S. Persinger, E. Civi,} S.W. Vostina write about such important properties as risk tolerance, trust and reciprocity, the value of autonomy, purposefulness, highlighting a new understanding of the effects from their return (Persinger et al., 2011). 
Estimates of private norms of the return of human capital appeared in the $1940 \mathrm{~s} .20^{\text {th }}$ century. G. Becker calculated the private rates of return for college graduates on the basis of data from the 1940 and 1950 censuses and of the subsequent years. His estimates of the rates of return were $14.5 \%$ in $1939,13 \%-1949,12.4 \%-1956$ and $14.8 \%$ in 1958, similar estimates for graduates of higher schools (general secondary school in the Russian classification) were $16 \%, 20 \%, 25 \%$ and $28 \%$, respectively (Becker, 1975). It can be said that a one year increase in education resulted in the growth of earnings by the rate of return in the USA at that period of time.

The research of A. de la Fuente and A. Ciccone shows that the additional year of education raises wages at an individual level by $6.5 \%$ on average in European countries and this effect reaches $9 \%$ in EU member states with a less regulated labor market. In addition, a year of additional field experience increases wages by almost $5 \%$. The authors believe that in member countries of the Organization for Economic Cooperation and Development, human capital provided up to $22 \%$ of the observed productivity growth during the period 1960-1990 and up to $45 \%$ of differences in labor productivity on average for these countries in the 1990s (De la Fuente, Ciccone, 2002).

E. Helpman describes research proving that during the $20^{\text {th }}$ century in the United States, about a quarter of the increase in the income indicator per employee was associated with an increase in the level of education (Helpman, 2009).

J. Psacharopoulos note that private rate of return of education is usually higher than the social rate of return where the latter is defined on the basis of private benefits but total (private plus external) costs (Psacharopoulos, 1994).

J. Mincer introduced a "production function of earnings", which describes the dependence of the logarithm of a worker's salary on the level of his education, length of service, length of time worked and other factors. He showed that the coefficient at a variable level of education would be equivalent to the value of the internal rate of return, which made it possible to significantly simplify the evaluation of the effectiveness of investments in education (Mincer, 1975).

The most interesting example of calculating the private rate of return of education in Russia is the study of a group of authors who consider the factors of differentiation of wages (monthly earnings and hourly rates) in terms of level of education, length of service, age and professional status (Gimpel'son, Luk'yanova, 2006). As a result of the calculation of the standard Mincer's equation, the economic impact of higher education was about $82 \%$ (compared to the average general education), that is, about $16 \%$ per year of education.

There are many attempts to obtain such estimates, but they vary greatly. Since macroeconomic estimates include most of the induced external benefits, while microeconomic estimates are only a fraction of these benefits, the difference between these two estimates can be interpreted as a measure of the magnitude of the externalities arising from human capital.

The importance of research on the use of human capital has been increasing for the last decades, as the role of knowledge and scientific and technological progress is increasing in the modern economy.

\section{Statement of the problem}

In the conditions of the emerging digital economy, factors affecting human capital are becoming more important. It becomes urgent to examine its characteristics, which serve as differentiation factors of employees' wages, i. e. to assess their rates of return. 


\section{Methods}

The authors suggest that apart from classical factors such as education, experience, place of residence, affecting the formation of human capital, other factors such as entrepreneurial abilities, high motivation for success and goal achievement, work in cyberspace can be also significant. The data were obtained on the basis of a survey of Siberian workers. The questioning is based on a group of general questions, questions about social and labor relations and the use of ICT, psychodiagnostics.

For the research, the following methods were used: psychodiagnostics of the degree of readiness for risk by Schubert (Golovey, Rybalko, 2001; Mironova, 2006); method of psychodiagnostics of personality on the motivation for the success of T. Ehlers (Golovey, Rybalko, 2001; Mironova, 2006); methodology for assessing the need to achieve Yu.M. Orlova (Golovey, Rybalko, 2001; Mironova, 2006); modification of the model of J. Mincer (Mincer, 1975).

Let's take a closer look at them.

Methodology of A.M. Schubert allows to evaluate the features of behavioral reactions of a person in situations associated with uncertainty, requiring violation of established norms, rules. It is recommended for the selection of employees suitable for work in a risk environment. The test consists of 25 questions, each of them has a list of suggested answers: I fully agree; rather yes than no; cannot say; rather no than yes; I strongly disagree. The score for each answer ranges from
-2 to 2 points. In order to use this technique in combination with the techniques by T. Ehlers and Yu.M. Orlova, it is necessary to come to a single system of points scoring, so let's move the numerical axis of the score values to the range from 0 to 4 . The result of the questionnaire is calculated according to the scored points (Table 3 ), on the basis of which a conclusion is made about a person's inclination to risky behavior.

The test can be carried out either individually or in a group. Total testing time is about 7 minutes. The overall assessment of the test is given on a continuous scale as a deviation from the mean. Positive responses indicate an inclination to risk. The author of the methodology notes that high readiness for risk is often accompanied by low motivation to avoid failures (or in other words, protection).

This test has an area of uncertainty in the ranges $(-30 ;-10)$ and $(10 ; 20)$, which may be called a drawback of this technique. But for our research, only the respondent's high risk appetite is important, which is typical only for the range $[20 ; 50]$, or in new scoring system - the range [70; $100]$.

Thus, it is possible to form a new table with an interpretation of the results of the survey (Table 4).

The following method of diagnosing of a person's motivation for success by T. Ehlers assesses the degree of aspiration to achieve the goal, success. The test has 41 questions. The degree of motivation to success is characterized

Table 3. Conclusions about a respondent's inclination to risky behavior according to A.M. Schubert using the new proposed score system

\begin{tabular}{|c|l|l|l|}
\hline No. & \multicolumn{1}{|c|}{$\begin{array}{c}\text { The number of points by } \\
\text { A.M. Schubert }\end{array}$} & $\begin{array}{l}\text { The number of points after changing } \\
\text { their values }\end{array}$ & \multicolumn{1}{|c|}{ Conclusions } \\
\hline 1 & Less than -30 & Less than 30 & Too cautious \\
\hline 2 & -10 to +10 & $40-60$ & Mean values \\
\hline 3 & More than +20 & More than 70 & Are prone to risk \\
\hline
\end{tabular}


Table 4. Changed interpretation of the results of the questionnaire based on the method of A.M. Schubert to identify risky behavior

\begin{tabular}{|c|l|l|l|}
\hline № & \multicolumn{1}{|c|}{ Score Range } & \multicolumn{1}{c|}{ Conclusions } & \multicolumn{1}{c|}{ Interpretation } \\
\hline 1 & {$[0 ; 70]$} & A high risk appetite is absent & Not typical for intrapreneurs \\
\hline 2 & {$[70 ; 100]$} & There is a high risk appetite & Characteristic of intraprenrators \\
\hline
\end{tabular}

Table 5. Results of the test of the degree of motivation for the success of respondents by T. Ehlers's method

\begin{tabular}{|c|l|l|}
\hline No. & \multicolumn{1}{|c|}{ Number of points } & \multicolumn{1}{c|}{ Conclusions } \\
\hline 1 & $1-10$ & Low motivation for success \\
\hline 2 & $11-16$ & Average level of motivation \\
\hline 3 & $17-20$ & Moderately high level of motivation \\
\hline 4 & More than 20 & Too high level of motivation for success \\
\hline
\end{tabular}

Table 6. Conclusions about the level of respondents' need to achieve their goals by the method of Yu.M. Orlova

\begin{tabular}{|c|c|c|c|}
\hline No. & Number of points & Level of motivation & Conclusions \\
\hline 1 & Less than 9 & 1 & \multirow[t]{3}{*}{ Low level of achievement } \\
\hline 2 & 10 & 2 & \\
\hline 3 & 11 & 3 & \\
\hline 4 & 12 & 4 & \multirow[t]{4}{*}{ Average level of achievement } \\
\hline 5 & 13 & 5 & \\
\hline 6 & 14 & 6 & \\
\hline 7 & 15 & 7 & \\
\hline 8 & 16 & 8 & \multirow[t]{3}{*}{ High level of achievement } \\
\hline 9 & 17 & 9 & \\
\hline 10 & More than 18 & 10 & \\
\hline
\end{tabular}

by the number of points that coincide with the rating system.

The higher the score, the higher the level of motivation to achieve success is. Possible test results are shown in Table 5 .

The motivation for success is one of the main characteristics of human capital, therefore, respondents who received 11 or higher scores will be of interest for the study.

The methodology for estimating the need for achievement was proposed by Yu.M. Orlov in 1978. It is aimed at studying the features of motivation of achievements. The test is recommended for studies of the impact of achievement motivation on the performance of organizations. Questionnaire Yu.M. Orlova includes 23 statements. The scoring scale contains values from 0 to 23 points. The possible results of the questionnaire are given in Table 6.

By analogy with the methodology for diagnosing a person's motivation for success by $\mathrm{T}$. Ehlers, the most interesting group of respondents for the research is the one with a higher level of motivation. Let us set the threshold value - 12 points, the achievement and exceeding 
of which will show the employee's motivation to achieve the goal.

The results of psychodiagnostics can be used in the modification of the Mincer's model, ensuring by their inclusion a high indicator of determination. $W$

J. Mincer proposed "the production function of earnings", which describes the dependence of the logarithm of a worker's salary on the level of his education, work experience, duration of working time and other factors. In a simplified form, the equation will be:

$\ln W_{i}=A+b_{1} h_{i}+g_{1} s_{i}+g_{2} s_{i}^{2}+u_{i} \quad$,

where $W_{i}$ is the wage in rubles; $h_{i}$ - education level of the i-th respondent in years; $s_{i}$ - work experience of the $\mathrm{i}$-th respondent.

He showed that the coefficient at the variable level of education will be equivalent to the value of the internal rate of return, which made it possible to significantly simplify the evaluation of the effectiveness of investments in education (Mincer, 1975).

In our opinion, it will be interesting to include in the model new fictitious variables such as a "place of residence" (allowing to make territorial gradation), "risk appetite" (which gives an opportunity to assess the influence of entrepreneurial abilities of an employee), "motivation for success" and "achieving the set goal" (As the characteristics of human capital, which can be considered together). The modified model takes the following form:

$$
\begin{aligned}
& \ln W_{i}=A+b_{0} H C_{\mathrm{i}}+b_{1} h_{i}+g_{1} s_{i}+g_{2} s_{i}^{2}+ \\
& +d_{1} D_{1}+d_{2} D_{2}+d_{3} D_{3}+b_{3} R_{i}+u_{i}
\end{aligned}
$$

where the variable D1 is the dummy variable which equals to 1 if the person lives in a metropolis, and 0 if in another place; D2 is the dummy variable equaling to 1 if the person lives in another regional center, 0 if in another place; D3 is a dummy variable that is equal to 1 if a person lives in the north areas, and 0 if in another place (this allows to allocate groups according to their place of residence); $\mathrm{HCi}$ is a dummy variable equal to 1 if the interviewee had a high motivation for success and sought to achieve the goals set and $0-$ in the opposite case. $\mathrm{Ri}$ is a dummy variable equal to 1 , if the respondent had a risk appetite and 0 in the opposite case.

Thus, the authors attempted to modify Mincer's model by introducing new factors for assessing externalities arising from human capital

\section{Discussion}

The analysis of the average wage level of workers in the Siberian Federal District, including freelancers, differs significantly from the data of the Federal Statistics Service of the Russian Federation (Fig. 1).

The high variation in the level of wages from official statistics is due to a small number of respondents. The sampling in 2013 was - 199 respondents, in 2014 - 178 people, in 2015 - 152 respondents, in 2016 - 181 people. The sample of freelancers in 2013 was 105 respondents, in 2014 - 80 people, in 2015 - 325 respondents, in 2016 - 52 respondents. According to the survey of freelancers in the Siberian Federal District, their average wage in 2015 was $28,430.77$ rubles, in $2016-43,288.46$ rubles.

During the same period, the following characteristics of freelancers were obtained. Their average work experience as a freelancer was 3.4 years. The average age of respondents is 28.1 years. The number of simultaneously executed orders strongly depends on the scope of employment and its size and amounted to 1.62 units. The average maximum duration of project absence is 13.5 days. The share of net freelancers was $37.14 \%$, we include those respondents who 


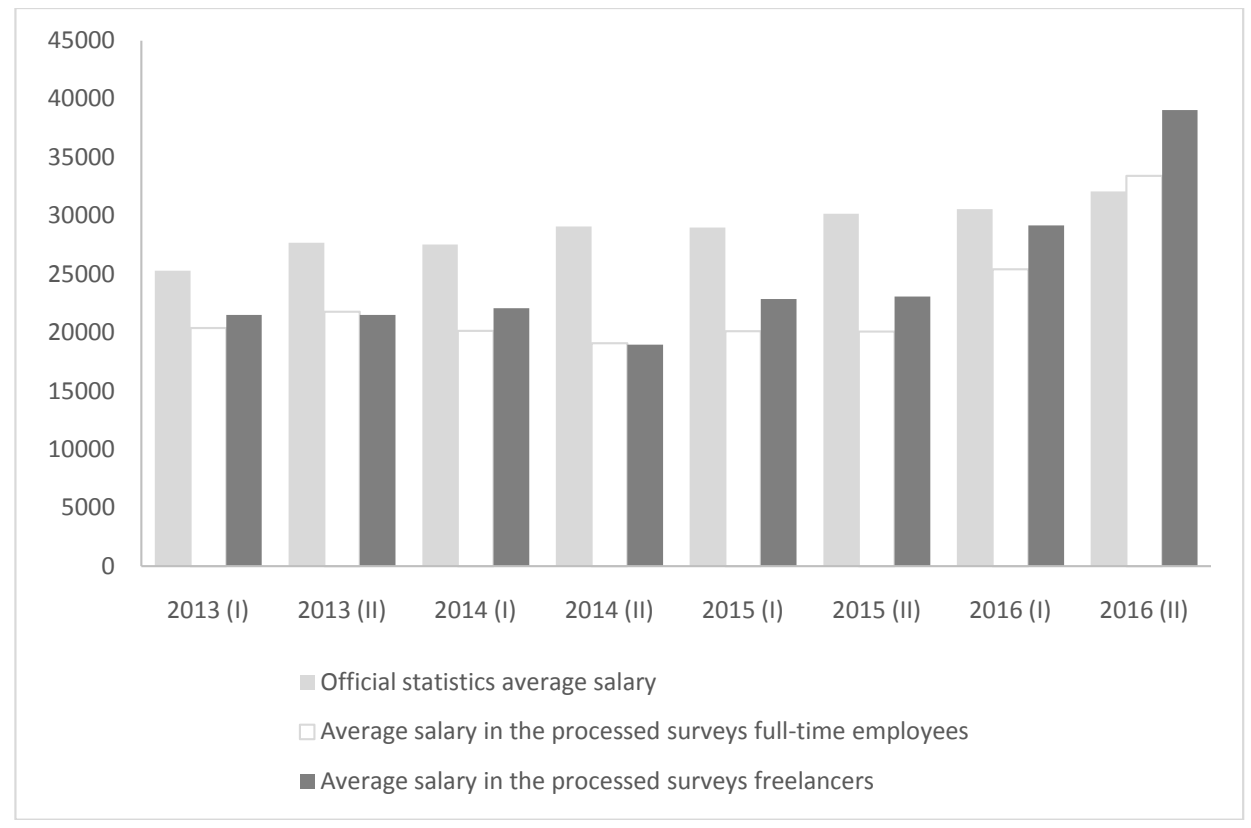

Fig. 1. Dynamics of the average wage level of workers in the Siberian Federal District

Table 7. The results of psychodiagnostics of Russian workers for the period 2014-2016

\begin{tabular}{|l|c|c|c|c|}
\hline \multicolumn{1}{|c|}{ Type of employees } & $\begin{array}{c}\text { Sample size, } \\
\text { respondents }\end{array}$ & Risk propensity, \% & $\begin{array}{c}\text { Motivation to } \\
\text { success, \% }\end{array}$ & $\begin{array}{c}\text { Achievement of the } \\
\text { goal, \% }\end{array}$ \\
\hline Freelancers & 376 & 2.93 & 99.2 & 100 \\
\hline $\begin{array}{l}\text { Employees only with } \\
\text { standard employment }\end{array}$ & 470 & 15.11 & 36.17 & 34.26 \\
\hline
\end{tabular}

do not have a permanent place of work. The rest of the freelancers are the last year students, graduate students; Workers with whom employment contracts are concluded on a permanent basis in various organizations, considering freelance as an additional income or temporarily unemployed.

The results of psychodiagnostics by modified methods. By Schubert, T. Ehlers, Yu.M. Orlov gave the following interesting results (Table 7).

Freelancers have a highmotivation for success and achievement of the goal $(99.2 \%$ and $100 \%$ respectively), they are vivid examples of human capital. The inclination to risk is quite specific, it is significantly lower than that of employees with standard employment. Respondents whose performance was high in all three tests, in our opinion, can be attributed to intrapreneurs. They are quite rare, because not all employees have entrepreneurial abilities. According to the results of our study, approximately the same results were obtained for the two groups of workers under consideration $-2.93 \%$ and $2.77 \%$.

Thus, employees who carry out their activities in cyberspace have a high motivation for success and achievement of the goal. They are the most competitive in modern conditions. If they also have a risk appetite, this speaks more about their entrepreneurial potential, which is necessary in any organization. It is this potential that will ensure competitiveness for the employee and the organization.

With the help of the modified Mincer's model, the impact of the level of education, work experience and other qualitative characteristics 
of Russian workers on their level of wages for the period 2014-2016 has been estimated. If the variables were not significant, they were excluded from the model. As a result, the following statistically significant models were obtained:

$$
\begin{gathered}
\ln W_{i}=0,974+0,421 H C_{\mathrm{i}}+0,047 h_{i}+0,002 s_{i}+0,070 D_{1} h_{i}+0,42 D_{3} h_{i}+u_{i} \\
(0,139) \quad(0,044) \quad(0,010) \quad(0,002) \quad(0,004)
\end{gathered}
$$

the coefficient of the regression equation determination is 0.617 , the Fisher criterion $(\mathrm{F})$ is 184.13, the significance is 0.000 , the number of respondents is 577; all the coefficients of the given regression equation are statistically significant at the $1 \%$ level;

$$
\begin{aligned}
& \ln W_{i}=0,966+0,083 h_{i}+0,005 s_{i}+1,313 D_{1}+1,241 D_{2}+0,790 D_{3}+u_{i}, \\
& \begin{array}{llllll}
(0,132) & (0,010) & (0,002) & (0,063) & (0,146) & (0,046)
\end{array}
\end{aligned}
$$

the coefficient of the regression equation determination is 0.618 , Fisher's exact test $(\mathrm{F})$ 184,83 , the significance is 0.000 , the number of respondents - 577 people; all the coefficients of the given regression equation are statistically significant at the $1 \%$ level;

$$
\begin{gathered}
\ln W_{i}=0,529+0,0361 H C_{\mathrm{i}}+0,062 h_{i}+0,004 s_{i}+1,183 D_{1}+1,041 D_{2}+0,683 D_{3}+0,228 R_{i}+u_{i}, \\
\begin{array}{lllllll}
(0,148) & (0,041) & (0,009) & (0,002) & (0,061) & (0,138) & (0,044)
\end{array}
\end{gathered}
$$

the coefficient of the regression equation determination is 0.667 , the Fisher criterion (F) is 163.21 , the significance is 0.000 , the number of respondents is 577; all coefficients of the given regression equation are statistically significant at the $5 \%$ level;

$$
\begin{gathered}
\ln W_{i}=0,128+0,515 H C_{\mathrm{i}}+0,11 h_{i}-0,0004 s_{i}-0,104 D_{3} h_{i}+0,022 D_{3} s_{i}+2,069 D_{3}+0,184 R_{i}+u_{i}, \\
\left(\begin{array}{lllllll}
0,183) & (0,047) & (0,012) & (0,002) & (0,029) & (0,006) & (0,456)
\end{array}\right.
\end{gathered}
$$

the coefficient of the regression equation determination is 0.540 , the Fisher's criterion (F) is 96.89 , the significance is 0.000 , the number of respondents is 577 ; all the coefficients of the given regression equation are statistically significant at the $10 \%$ level;

Thus, respondents' self-assessments supplement their objective characteristics, that is, variables: the level of education of an employee, length of service and fictitious variables that characterize residences that are all statistically significant regressors, and provide an increase in the level of wages.

The private rate of return of education at first glance turned out to be quite low $-4.7 \%$ per year of education. This is true for small towns and villages. The coefficients for the variables $D_{3} h_{i}$ and $D_{1} h_{i}$ are $4.2 \%$ and $7 \%$, respectively. Consequently, in the large regional centers of Siberia the private rate of education is higher than the average and is $8.9 \%$, and in northern cities and towns it is even higher $(11.7 \%)$. The level of wages according to our analysis, on average, irrespective of the level of education and seniority was higher in the large cities of Siberia and northern cities and towns. Introduction of additional variable D1si into the model made it possible to reveal the following features. In northern Siberia, work experience 
has a significant positive effect on wages, an increase of more than $2 \%$ per year of service. At the same time, unlike other regions, the average private rate of return of education is lower, the year of education adds less than $1 \%$ to wages. It can be concluded that at the enterprises of the primary industries prevailing in the north of Siberia, human capital is less valued, the practical experience of work is more in demand.

A separate study was conducted for freelancers and employees only with standard forms of employment. According to the data of 2015 , the rate of private pay for education was $11.2 \%$ for each year of education. The increase in total length of service for one year increased wages by $3.6 \%$. The work experience as a freelancer increased the wage level by $7.2 \%$ in the first case (Aletdinova, 2016). They are close to the indicators of Siberian workers with standard employment. The data for 2016 show the already differentiated level of wages against the background of its overall growth. Statistically significant for the data of 2016 was an indicator of the propensity to take risks.

\section{Conclusion}

Digitalization of the economy is possible with the development of digital infrastructures and communication standards; maintenance of information security in it; expanding online learning; creation of free access to all citizens for the network and online communications in it; improving the management of information flows and knowledge in digital ecosystems; the formation of digital culture and the accumulation of human capital. In these conditions, the requirements for labor resources are changing, workers are not enough to receive only a classical education. They must engage in constant self-improvement, selfdevelopment, continuous education; be able to think critically and systematically, quickly adapt to rapidly changing conditions; fluent in foreign languages. The authors analyzed the main factors affecting the level of workers wages in Siberia. Cyberspace workers, such as freelancers, are distinguished not only by high labor mobility, but also by a high motivation for success and the need to achieve this goal. Human capital in the era of the digital economy development has a greater return and is becoming more and more in demand.

\section{References}

Avdeev, R.F. (1994) Filosofiya informatsionnoy tsivilizatsii [Philosophy of Information Civilization]. Moscow, Vlados, 336 p.

Aletdinova, A.A. (2016). Peculiarities of the Russian Freelance Market. In Zhurnal Sibirskogo federal'nogo universiteta. Gumanitarnyye nauki [Journal of Siberian Federal University. Humanities \& Social Sciences], 9(11), 2734-2741.

Aubert, B.A., Kelsey, B.L. (2003). Further understanding of trust and performance in virtual teams. In Small Group Research, 34(5), 575.

Badinger, H., Tondl, G. (2002). Trade. Human Capital and Innovation: The Engines of European Regional Growth in the 1990-s. In IEF Working Paper, 42, 15.

Becker, G.S. (1975). Human Capital: A Theoretical and Empirical Analysis, with Special Reference to Education. New York, Columbia University Press for NBER, 44 p.

Becker, G.S. (1994). Human capital revisited. Human Capital: A Theoretical and Empirical Analysis with Special Reference to Education. Chicago, The University of Chicago Press, 960 p.

De la Fuente, A. Ciccone, A. (2002). Human capital in a global and knowledge-based economy. In Report for European Comission. Berlin, Institute for Economic Analysis, 3-4. 
Fulk, J., DeSanctis, G. (1995). Electronic communication and changing organizational forms. In Organization Science, 6(4), 337-349.

Gimpel'son V., Luk'yanova A. (2006). «O bednom byudzhetnike zamolvite slovo...»: mezhsektornyye razlichiya v zarabotnoy plate ["On a poor state budget, say the word ...": intersectoral differences in wages.]. In Voprosy ekonomiki [Issues of economics], 6, 81-82.

Golovey, L.A., Rybalko, Ye.F. (2001). Praktikum po vozrastnoy psikhologii [Workshop on Age Psychology]. St. Petersburg, Rech, $694 \mathrm{p}$.

Government of the RF. (2011). Draft Concept of Innovative Development until 2020; available at: http://www.economy.gov.ru/minec/main

Helpman, E. (2009). The mystery of economic growth. Harvard, Harvard University Press, 447 p.

Kane, G.C., Palmer, D., \& Phillips, A.N., Kiron, D. (2017). Winning the digital war for talent. In MIT Sloan Management Review, 58.2, 17.

Kirnen, M. (2004). Obnovlyay ili umri. Kak sozdat' konkurentosposobnuyu kompaniyu XXI veka [Renew or die. How to create a competitive company of the 21st century]. Moscow, Krylov, $384 \mathrm{p}$.

Kuehl, D.T. (2009). From cyberspace to cyberpower: Defining the problem. In Cyberpower and national security, 1, 24-42.

Kupriyanovskiy V.P., Sukhomlin V.A., \& Dobrynin A.P., Raykov A.N., Shkurov F.V., Drozhzhinov V.I., Fedorova N.O., Namiot D.Ye. (2017). Navyki v tsifrovoy ekonomike i vyzovy sistemy obrazovaniya [Skills in the digital economy and the challenges of the education system]. In International Journal of Open Information Technologies, 1, 19-25.

Levchenko, O.M., Tsarenko I.O. (2016). Higher education as a factor of human capital development. In Proc. International Scientific-Practical Conference «Modern Transformation of Economics and Management in the Era of Globalization». Klaipeda, 175-179.

Luksha P., Luksha K., \& Varlamova D., Sudakov D., Peskov D., Korichin D. (2014). Atlas novykh professiy [Atlas of new professions]. Moscow, Skolkovo, 168 p.

Mincer, J. (1975). Schooling, experience and earnings. New York, NBER, 176 p.

Mironova, E.E. (2006). Sbornik psikhologicheskikh testov [Collection of psychological tests]. Minsk, ENVILA, 2, 146 p.

Nureyev, R.M. (2009). Rossiya: osobennosti institutsional'nogo razvitiya [Russia: Specific Features of Institutional Development]. Moscow, Publisher NORM, 448 p.

OECD. (2016). Skills for a Digital World 2016. Ministerial Meeting on the Digital Economy. Background Report № 250; available at: http://www.oecd-ilibrary.org/science-and-technology/skillsfor-a-digital-world_5jlwz83z3wnw-en Retrieved: Dec, 2016

Persinger, E.S., Civi, E., \& Vostina, S.W. (2011). The born global entrepreneur in emerging economies. In International Business \& Economics Research Journal, 6 (3), 73-82.

Privman, R., Hiltz, S.R., \& Wang, Y. (2013). In-group (us) versus out-group (them) dynamics and effectiveness in partially distributed teams. In IEEE Transactions on Professional Communication, 56(1), 33-49.

Psacharopoulos, G. (1994). Returns to investment in education: a global update. In World Development, 22(9), 1325-1343.

Pvc company (2016). "Industriya 4.0»: sozdaniye tsifrovogo predpriyatiya. Vsemirnyy obzor realizatsii kontseptsii «Industriya 4.0» za 2016 god ["Industry 4.0": the creation of a digital enterprise. World review of the implementation of the concept of "Industry 4.0" for 2016], available at: http:// www.pwc.ru/ru/technology/assets/global_industry-2016_rus.pdf 
Radayev, V.V. (2003). Ponyatiye kapitala, formy kapitalov i ikh konvertatsiya [The concept of capital, forms of capital and their conversion]. In Obshchestvennyye nauki i sovremennost' [Social Sciences and Modernity], 2, 5-16.

Schultz, T. (1971). Investment in Human Capital. N.Y., The Free Press, 28 p.

Smith, A. (1976). An Inquiry into the Nature and Causes of the Wealth of Nations. Oxford, Oxford Univ. Press, 985 p.

Smorodinskaya, N.V. (2015). Globalizirovannaya ekonomika: ot iyerarkhiy k setevomu ukladu [The globalized economy: from hierarchies to a networked way of life]. Moscow, Institute of Economics of the RAS, $344 \mathrm{p}$.

Tuguskina, G.N. (2009). Otsenka chelovecheskogo kapitala $v$ stoimosti biznesa: teoriya, metodologiya, praktika [Evaluation of human capital in business value: theory, methodology, practice]. Penza, Information and Publishing Center of PSU, $186 \mathrm{p}$.

Vdovenko, Z.V., Kharchenko, N.V. (2003). Ekonomicheskiy aspekt globalizatsii s pozitsii innovatsionnogo podkhoda [The economic aspect of globalization from an innovative approach]. In Vestnik Kuzbasskogo gosudarstvennogo tekhnicheskogo universiteta [Bulletin of the Kuzbass State Technical University], 6, 136-142.

Vernadskiy, V.I. (2004). Biosfera i noosfera [Biosphere and noosphere]. Moscow, Ayris Press, 576 p.

Working group of the Eurasian Economic Union. (2016). Strategiya razvitiya tsifrovogo prostranstva YEAES 2025 [Strategy for the development of the digital space of the EAEC 2025]; available at: http://d-russia.ru/wp-content/uploads/2016/10/strategy.pdf

\title{
Человеческий капитал Сибири
}

в эпоху развития цифровой экономики

\author{
А.А. Алетдинова, А.В. Корицкий \\ Новосибирский государственный технический университет \\ Россия, 630073, Новосибирск, пр. Карла Маркса, 20
}

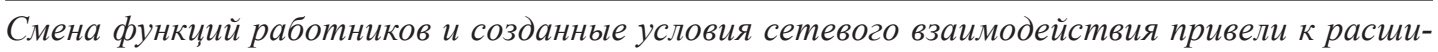
рению форм занятости, изменению режимов рабочего времени, стиранию территориальных рамок, повыщению гибкости труда, переноса хозяйственной, общественной деятельности в киберпространстве. В эпоху развития иифровой экономики человеческий капитал стал более востребованным и имеет большую отдачу. Это подтверждается расчетами и интерпретацией модифицированного уравнения Минцера. Работники должны заниматься постоянно саморазвитием, непрерывным образованием; уметь мыслить критически и системно, быстро адаптироваться к меняющимся условиям; свободно владеть иностранными языками, стремиться к достижению поставленных иелей, быть настроенным на успех. Результать анкетирования показывают, что фрилансеры в отличие от работников со стандартной занятостью больше соответствуют этим требованиям.

Ключевые слова: ичирровая экономика, сетевое взаимодействие, человеческий капитал, методы психодиагностики, модифицированное уравнение Минцера.

Научная специальность: 08.00.00 - экономические науки. 